\title{
ANALISIS FAKTOR PEMBERIAN IMUNISASI RUBELLA DI KELURAHAN WAKANGKA KABUPATEN BUTON
}

\author{
Rininta Andriani ${ }^{1}$, Wahyuddin ${ }^{1 凶}$, Agus Darmawan ${ }^{1}$ \\ ${ }^{1}$ Fakultas Ilmu Kesehatan Masyarakat, Universitas Dayanu Ikhsanuddin Baubau
}

\begin{tabular}{l} 
ARTICLE INFO \\
\hline Article history
\end{tabular}

Submitted : 2020-01-18

Revised : 2020-01-21

Accepted : 2020-01-21

Keywords:
Rubella Immunization
Knowledge
Attitude
Religion

\section{Kata Kunci:}

Imunisasi Rubella, Pengetahuan Sikap Agama

\begin{abstract}
Rubella disease is a contagious disease that can be prevented by immunization. This disease is characterized by the appearance of a rash and mild fever or similar to other viral diseases such as measles and scarlet fever. Rubella is more common in adults than in children. In adults, $70 \%$ of cases of rubella disease cause arthritis or atrophy and joint pain. This study aims to determine the relationship of knowledge, attitudes and religion in the administration of rubella immunization in Wakangka Village, Kapontori District. This type of research is quantitative analytic observational approach is a study that explains the relationship between variables through hypothesis testing. The number of samples was 72 people. Samples were taken using simple random sampling technique. Data analysis using univariate and bivariate analysis using chi square test is to see the relationship between variables. The results showed knowledge with a value of $\mathrm{p}=0,000$ $(\alpha<0.05)$, maternal attitudes with a value of $p=0,000(\alpha<0.05)$, and religion with a value of $p=0.995(\alpha>0.05)$. The conclusion in this study is that there is a relationship between knowledge and attitudes with the provision of Rubella Immunization, but there is no relationship between religion and Rubella immunization. It is recommended that people who have children aged 5 months to 15 years be rubella immunized to avoid being recorded.

Penyakit Rubella merupakan salah satu penyakit menular yang dapat dicegah dengan imunisasi. Penyakit ini ditandai dengan munculnya ruam dan demam ringan atau yang mirip dengan gejala penyakit viral lainnya seperti campak dan demam scarlet. Rubella lebih sering muncul pada orang dewasa dibandingkan pada anak-anak. Pada orang dewasa, 70\% kasus infeksi penyakit Rubella menyebabkan terjadinya artritis atau atralgi dan nyeri sendi. Penelitian ini bertujuan untuk mengetahui hubungan pengetahuan, sikap dan agama dalam pemberian imunisasi rubella di Kelurahan Wakangka Kecamatan Kapontori. Jenis penelitian ini adalah kuantitatif dengan pendekatan observasional analitik merupakan penelitian yang menjelaskan adanya hubungan antar variabel melalui pengujian hipotesis. Jumlah sampel sebanyak 72 orang. Sampel diambil menggunakan teknik simple random sampling. Analisis data menggunakan analisis univariat dan bivariat dengan menggunakan uji chi square yaitu untuk melihat hubungan antar variabel. Hasil penelitian menunjukan pengetahuan dengan nilai $p=$ $0,000(\alpha<0,05)$, sikap ibu dengan nilai $p=0,000(\alpha<0,05)$, dan agama dengan nilai $p$ $=0,995(\alpha>0,05)$. Kesimpulan dalam penelitian ini yaitu terdapat hubungan antara pengetahuan dan sikap dengan pemberian Imunisasi Rubella namun tidak terdapat hubungan antara Agama dengan pemberian Imunisasi Rubella. Disarankan kepada masyarakat yang memiliki anak usia 5 bulan sampai 15 tahun untuk diimunisasi rubella agar terhindar dari kecatatan.
\end{abstract}

$\triangle$ Corresponding Author:

Wahyuddin

Fakultas Ilmu Kesehatan Masyarakat, Universitas Dayanu Ikhsanuddin Baubau

Telp. 085241952936

Email: wahyu4977@gmail.com

\section{PENDAHULUAN}

Penyakit Rubella merupakan salah satu penyakit menular yang dapat dicegah dengan imunisasi. Penyakit ini ditandai dengan munculnya ruam dan demam ringan atau yang mirip dengan gejala penyakit viral lainnya seperti campak dan demam scarlet. Rubella juga muncul dengan sedikit keluhan atau bahkan tanpa gejala. Rubella lebih sering muncul pada orang dewasa dibandingkan pada anak-anak. Pada orang dewasa, $70 \%$ kasus infeksi penyakit Rubella menyebabkan terjadinya artritis atau atralgi dan nyeri sendi. Infeksi penyakit Rubella pada anak sering 
dianggap penyakit ringan, namun apabila virus Rubella menginfeksi ibu hamil pada usia kehamilan kurang dari 20 minggu dapat menyebabkan masalah yang serius Sejak ditemukan pada abad ke 18, Rubella menjadi penyakit yang minim perhatian karena dianggap tidak menimbulkan masalah yang serius (Pramitasari \& Puteri, 2017). Kemudian pada tahun 1941 peneliti asal Australia, Michael Greg, menemukan hubungan antara infeksi Rubella pada awal kehamilan dengan kejadian katarak pada bayi baru lahir (Merlinta, 2018).

Sementara di Amerika Serikat, sebelum adanya vaksin Rubella pada tahun 1969, kasus Rubella meningkat setiap $6-9$ tahun terutama di musim dingin dan awal musim semi. Setelah tersedia vaksin untuk Rubella, terjadi penurunan kasus di negara-negara maju seperti Eropa.

Hal ini didukung dengan komitmen untuk mengeliminasi Rubella dan CRS di Eropa pada tahun 2017. Data WHO tahun 2017 menyebutkan kasus Rubella yang dilaporkan berkurang 98\% dari 512.128 kasus di tahun 2010 menjadi 10,532 kasus di tahun 2017. Begitupun dengan di Amerika Serikat dimana penurunan kasusnya hampir $100 \%$ di tahun 2017 (Mardijanto \& Hasanbasri, 2017). Setelah tersedia vaksin untuk Rubella, terjadi penurunan kasus di negara-negara maju seperti Eropa. Dinas Kesehatan Provinsi Sulawesi Tenggara menargetkan 825.562 anak usia 9-15 tahun terimunisasi MR (Dinkes Provinsi Sulawesi Tenggara, 2018). Dalam implementasinya telah dilakukan $42 \%$ sejak 1 agustus 2018 dari targen 95\%. Data dinas kesehatan Provinsi Sulawesi Tenggara pada tahun 2018 terdapat 21 penderita MR dan 10 diantaranya di Kota Kendari, sedangkan campak sebanyak 298 penderita (Dinkes Provinsi Sulawesi Tenggara, 2019).

Pemberian imunisasi MR (Measles Rubella) pada anak usia 9 bulan hingga kurang 15 tahun di Kabupaten Buton mencapai 73,72 $\%$ dari target nasional $95 \%$. Untuk mencapai target tersebut, kami terus melakukan kunjungan pada masing-masing Puskesmas dan posyandu di wilayah Buton, serta melakukan pendataan atau menginventarisir sekolahsekolah yang capaian persentasenya di bawah $50 \%$ selanjutnya di laporkan ke dinas pendidikan setempat yang bertujuan agar dinas kesehatan menyampaikan kepada puskesmas untuk kembali melakukan sosialisasi mengenai pentingnya imunisasi MR (Measles Rubella) (Dinkes Kabupaten Buton, 2019).

Di Puskesmas Kapontori Kabupaten Buton, capaian imunisasi MR (Measles Rubella) mencapai $85 \%$ dari target nasional 95\% hal ini dikarenakan saat awal pelaksanaan imunisasi ada pro kontra di masyarakat terkait halal dan haramnya Vaksin MR sehingga mempengaruhi pemahaman masyarakat untuk melaksanakan imunisasi MR dengan metode pendekatan pihak puskesmas selalu meyakinkan kepada masyarakat, tokoh masyarakat, serta dinas terkait sehingga masyarakat menjadi yakin bahwa imunisasi sangatlah penting (Dinkes Kabupaten Buton, 2018). Tujuan penelitian yaitu untuk mengetahui faktor-faktor yang berhubungan dengan karakteristik masyarakat dalam pemberian imunisasi Rubella di Kelurahan Wakangka Kecamatan Kapontori.

\section{METODE PENELITIAN}

\section{Jenis Penelitian}

Jenis penelitian ysng digunakan adalah adalah kuantitatif dengan rancangan cross sectional study.

\section{Lokasi Penelitian}

Lokasi penelitian dilaksanakan di Kelurahan Wakangka Kabupaten Buton. Penelitian dilaksanakan pada bulan Februari sampai Maret 2019.

\section{Populasi dan Sampel}

Populasi dalam penelitian ini adalah seluruh masyarakat yang mempunyai anak umur 5 bulan sampai 15 tahun di Kelurahan Wakangka Kecamatan Kapontori sebanyak 257 orang. Jumlah sampel dalam penelitian ini sebanyak 72 responden. Penarikan sampel menggunakan Rumus slovin dengan margin error 0,05. Teknik pengambilan sampel dalam penelitian ini yaitu simple random sampling.

$$
\begin{aligned}
n & =\frac{N}{1+N \mathrm{e}^{2}} \\
n & =\frac{257}{1+\left(257 \times 0,05^{2}\right)} \\
n & =\frac{257}{1+\left(257 \times 0,05^{2}\right)} \\
& =72
\end{aligned}
$$




\section{Pengumpulan Data}

Jenis dan teknik pengumpulan data dalam penelitian ini adalah data primer diperoleh dengan cara memberikan pertanyaan kepada responden yang mengacu pada kuesioner yang dibagikan berdasarkan kriteria yang telah ditetapkan dan data sekunder diperoleh dari Profil Kelurahan Wakangka.

\section{Pengolahan dan Analisis Data}

Pengolahan dan penyajian data dilakukan dengan menggunakan alat bantu komputer yaitu pemeriksaan data, pemberian kode, pemasukan data, pembersihan data, dan tabulasi. Teknik analisis data dalam penelitian ini adalah analisis univariat yang bertujuan untuk menjelaskan atau mendeskripsikan setiap variabel penelitian.

Pada umumnya dalam analisis ini hanya menghasilkan distribusi dan persentase dari setiap variabel. Analisis bivariat adalah analisis yang dilakukan terhadap dua variabel yang diduga berhubungan atau berkorelasi, uji yang dipakai adalah Chi-Square dengan batas kemaknaan $\alpha=0,05$.

\section{HASIL PENELITIAN}

Berdasarkan hasil pengolahan data yang telah dilakukan, maka disajikan hasil penelitian sebagai berikut :

Tabel 1. Distribusi Frekuensi Berdasarkan Karakteristik Responden

\begin{tabular}{lcc}
\hline \multicolumn{1}{c}{$\begin{array}{c}\text { Karakteristik } \\
\text { Responden }\end{array}$} & n & \% \\
\hline Kelompok Umur & & \\
$21-26$ & 32 & 44,5 \\
$27-32$ & 23 & 32 \\
$33-38$ & 12 & 16,7 \\
$39-45$ & 5 & 7 \\
\hline Pekerjaan & & \\
Petani & 39 & 54,2 \\
Wiraswasta & 6 & 8,3 \\
Ibu rumah tangga & 27 & 37,5 \\
\hline Pendidikan Terakhir & & \\
SD & 15 & 20,8 \\
SMP & 21 & 29,2 \\
SMA & 32 & 44,4 \\
Perguruan Tinggi & 4 & 5,6 \\
\hline Data primer 2019 & &
\end{tabular}

Data primer, 2019
Hasil penelitian tentang karakteristik responden menunjukkan bahwa dari 75 responden kelompok umur responden yang tertinggi yaitu kelompok umur 21-26 tahun sebanyak 32 responden dengan presentase $44,5 \%$ dan yang terendah adalah kelompok umur 39-45 tahun dengan jumlah 5 responden dengan presentase sebesar $7 \%$. Berdasarkan pekerjaan menunjukkan bahwa sebagai petani sebanyak 39 responden dengan presentase $954,2 \%$ lebih tinggi dari pada wiraswasta sebanyak 6 responden dengan presentase sebesar $8,3 \%$. pendidikan tertinggi yaitu SMA sebanyak 32 responden dengan presentase $44,4 \%$ dan yang terendah adalah perguruan tinggi sebanyak 4 responden dengan presentase sebesar $5,6 \%$.

Tabel 2. Distribusi Frekuensi Berdasarkan Variabel Penelitian

\begin{tabular}{lcc}
\hline Variabel Penelitian & n & \% \\
\hline Imunisasi Rubella & & \\
Imunisasi & 31 & 43,1 \\
Tidak imunisasi & 41 & 56,9 \\
\hline Pengetahuan ibu & & \\
Cukup & 19 & 26,4 \\
Kurang & 53 & 73,6 \\
\hline Sikap & & \\
Mendukung & 21 & 29,2 \\
Tidak mendukung & 51 & 70,8 \\
\hline Agama & & \\
Muslim & 43 & 59,7 \\
Non muslim & 29 & 40,3 \\
\hline
\end{tabular}

Data primer, 2019

Berdasarkan variabel yang diteliti menunjukkan variabel imunisasi rubella yang di imunisasi yaitu sebanyak 31 responden dengan persentase $43,1 \%$, dan tidak di imunisasi sebanyak 41 responden (56,9\%). Variabel pengetahuan ibu cukup yaitu sebanyak 19 responden dengan persentase $26,4 \%$, dan kurang sebanyak 53 responden $(73,6 \%)$. Variabel sikap mendukung yaitu sebanyak 21 responden dengan persentase $29,2 \%$, dan tidak mendukung sebanyak 51 responden (70,8\%). Variabel agama yaitu muslim sebanyak 43 responden dengan persentase $59,7 \%$, dan non muslim sebanyak 29 responden $(40,3 \%)$.

Hasil analisis variabel pengetahuan ibu menunjukkan bahwa berdasarkan hasil uji statistik dengan tingkat kepercayaan 95\% 
dengan ini nilai $\mathrm{p}=0,001$ lebih kecil dari $\alpha$ maka Ho ditolak dan Ha diterima berarti ada hubungan antara pengetahuan ibu dengan pemberian imunisasi Rubella di Kelurahan Wakangka Kecamatan Kapontori.

Variabel sikap menunjukkan bahwa berdasarkan hasil uji statistik dengan tingkat kepercayaan 95\% dengan ini nilai $\mathrm{p}=0,001$ lebih kecil dari a maka Ho ditolak dan Ha diterima berarti ada hubungan antara sikap ibu dengan pemberian imunisasi Rubella di Kelurahan Wakangka Kecamatan Kapontori. Pada variabel Agama menunjukkan bahwa berdasarkan hasil uji statistik dengan tingkat kepercayaan 95\% dengan ini nilai $\mathrm{p}=$ 0,995 lebih besar dari $\alpha$ maka Ho diterima dan Ha ditolak berarti tidak ada hubungan antara agama dengan pemberian imunisasi Rubella di Kelurahan Wakangka Kecamatan Kapontori.

Tabel 3. Analisis Faktor-Faktor yang Berhubungan dengan Karakteristik Masyarakat dalam Pemberian Imunisasi Rubella

\begin{tabular}{lccccccc}
\hline \multicolumn{1}{c}{ Variabel } & \multicolumn{3}{c}{$\begin{array}{c}\text { Status Imuniasi Rubella } \\
\text { Imunisasi }\end{array}$} & \multicolumn{2}{c}{ Total } & $\begin{array}{c}\text { Uji } \\
\text { Tidak Imunisasi } \\
\end{array}$ \\
& $\mathbf{n}$ & $\mathbf{\%}$ & $\mathbf{n}$ & $\mathbf{\%}$ & $\mathbf{n}$ & $\mathbf{\%}$ & Chi Square \\
\hline Pengetahuan & & & & & & & \\
$\quad$ Cukup & 15 & 75 & 5 & 25 & 20 & 100 & $\rho=0,001$ \\
$\quad$ Kurang & 16 & 30,8 & 36 & 69,2 & 52 & 100 & \\
$\quad$ Jumlah & 31 & 43,1 & 41 & 56,9 & 72 & 100 & \\
Sikap & & & & & & & \\
$\quad$ Mendukung & 16 & 76,2 & 5 & 23,8 & 21 & 100 & $\rho=0,001$ \\
$\quad$ Tidak Mendukung & 15 & 29,4 & 36 & 70,6 & 51 & 100 & \\
$\quad$ Jumlah & 31 & 43,1 & 41 & 56,9 & 72 & 100 & \\
$\quad$ Agama & & & & & & & \\
$\quad$ Muslim & 18 & 41,9 & 25 & 58,1 & 43 & 100 & $\rho=0,995$ \\
$\quad$ Non Muslim & 13 & 44,8 & 16 & 55,2 & 29 & 100 & \\
$\quad$ Jumlah & 31 & 43,1 & 41 & 56,9 & 72 & 100 & \\
\hline Data Primer 2019 & & & & & & &
\end{tabular}

\section{PEMBAHASAN}

\section{Hubungan Pengetahuan Ibu dengan Pemberian Imunisasi Rubella}

Pengetahuan merupakan suatu hal yang sangat dibutuhkan dalam rangka perubahan pola pikir dan perilaku suatu kelompok dan masyarakat. Pengetahuan ini terkait dengan lingkungan dimana mereka berada. Keadaan lingkungan sekitar sedikit banyak mempengaruhi pengetahuan, dalam hal ini pengetahuan mengenai kehamilan dan persalinan. Disamping itu kerterpaparan dengan media komunikasi akan mempengaruhi kadar pengetahuannya (Suprapto, 2007). Berdasarkan hasil penelitian menunjukkan bahwa dari 72 responden yang mengatakan pengetahuan cukup dengan imunisasi rubella yang diimunisasi sebanyak 15 responden, dan tidak di imunisasi sebanyak 4 responden, hal ini dikarenakan para ibu memiliki pengetahuan yang cukup dengan alasan mengetahui manfaat pemberian imunisasi Rubella pada anak selain itu para ibu meyakini bahwa pemberian imunisasi Rubella bertujuan agar terhindar dari penyakit akibat tidak di imunisasi

Responden yang mengatakan pengetahuan kurang dengan imunisasi Rubella yang di imunisasi sebanyak 16 responden dan tidak di imunisasi sebanyak 37 responden. Hal ini dikarenakan sebagian ibu di Kelurahan Wakangka memiliki pengetahuan yang kurang dikarenakan tingkat pendidikan ibu yang rendah, kurangngnya sarana informasi yang berupa brosur dan poster tentang imunisasi Rubella selain itu partisipasi dari petugas kesehatan atau kader posyandu harus lebih banyak melakukan pemantauan sehingga warga ingin melakukan imunisasi rubella hal tersebut sangat berdampak pada kurangnya pengetahuan ibu tentang imunisasi rubella di kelurahan wakangka. Hal ini sejalan dengan penelitian yang dilakukan oleh (Merlinta, 2018) dengan judul hubungan pengetahuan tentang vaksin MR dan pendidikan ibu terhadap minat 
keikutsertaan vaksinasi MR di Puskesmas Kartasura dimana hasil penelitian menunjukan bahwa terdapat hubungan yang signifikan antara pengetahuan terhadap minat keikutsertaan vaksinasi MR di Puskesmas Kartasura.

\section{Hubungan Sikap dengan Pemberian Imunisasi Rubella}

Sikap (Attitude) menurut (Yuliani, 2012) adalah kesiapan atau kesediaan seseorang untuk bertingkah laku atau merespon rangsangan positif maupun negatif dari suatu obyek rangsangan. Reaksi perasaan terhadap suatu obyek yaitu kegiatan pemberian imunisasi, baik perasaan yang mendukung atau tidak mendukung kemudian akan terwujud di dalam perilaku tertentu yang terjadi di dalam masing-masing individu masyarakat.

Berdasarkan hasil penelitian menunjukkan bahwa dari 72 responden yang mengatakan sikap mendukung dengan imunisasi Rubella yang di imunisasi sebanyak 16 responden, dan tidak di imunisasi sebanyak 5 responden, hal ini dikarenakan para ibu memiliki antusias untuk membawa anaknya di imunisasi Rubella dengan alasan tidak di lakukan satu bulan sekali dan imunisasi ini hanya diberikan selama 1 kali dalam hidup. Sedangkan yang mengatakan sikap tidak mendukung dengan imunisasi Rubella yang di imunisasi sebanyak 15 responden dan tidak di imunisasi sebanyak 36 responden, hal ini dikarenakan sebagian ibu memiliki sikap kurang dengan alasan jarak antara tempat imunisasi dengan rumah sangat jauh sehingga ibu malas membawa anaknya untuk melakukan imunisasi rubela, selain itu para ibu kurang mendukung tentang kegiatan imunisasi yang dilakukan oleh petugas kesehatan disebabkan para ibu tidak mau anak mereka untuk di imunisasi dengan alasan sudah terjadi kematian akibat diimunisasi Rubella.

Sejalan dengan penelitian yang dilakukan oleh Pramitasari yang judul hubungan pengetahuan dan sikap ibu dengan kepatuhan dalam mengikuti imunisasi MR massal di posyandu wilayah kerja Puskesmas Nganglik II Kabupaten Sleman Yogyakarta dimana hasil penelitian menunjukan bahwa terdapat hubungan yang signifikan antara sikap dengan kepatuhan dalam mengikuti imunisasi MR (Pramitasari \& Puteri, 2017). Hal ini akan meningkatkan resiko MR pada bayi jika tidak dilakukan Imunisasi. Penelitian stefanofik dkk tahun 2016 di menyatakan orang tua yang tidak ingin memberikan vaksinasi MR kepada anakanak mereka beresiko mengalami infeksi rubela selama kehamilan dan kemudian kehilangan anak atau melahirkan bawaan sindrom rubella (Stefanovic et al., 2016).

\section{Hubungan Agama dengan Pemberian Imunisasi Rubella}

Sudut pandang agama yang dimaksud dalam penelitian ini yaitu keyakinan masyarakat di kelurahan wakangka terkait tuhan pencipta alam. Indikator agama dalam penelitian ini yaitu masyarakat yang beragama muslim dalam artian beragama islam dan non muslim dalam kehidupan sehari-hari di Kelurahan Wakangka. Berdasarkan hasil penelitian menunjukkan bahwa dari 72 responden yang mengatakan agama muslim dengan imunisasi Rubella yang di imunisasi sebanyak 18 responden, dan tidak di imunisasi sebanyak 25 responden, hal ini dikarenakan para ibu yang berstatus agama muslim menganggap bahwa vaksin Rubella haram karena mengandung minyak babi sehingga mereka malas membawa anak untuk di imunisasi sedangkan yang mengatakan agama non muslim dengan imunisasi Rubella yang di imunisasi sebanyak 13 responden dan tidak di imunisasi sebanyak 16 responden hal ini dikarenakan para ibu yang berstatus non muslim tidak menganggap bahwa vakisin rubbela tidak sejalan dengan keyakinan yang mereka anut, para ibu lebih mengutamakan keselamatan anak mereka sehingga antusias ibu dalam kegiatan imunisasi sangat mendukung.

Penelitian ini di dukung dengan penelitian yang dilakukan oleh (Gustikawati, 2014) yang mengatakan bahwa pengalaman memiliki sifat yang sangat berharga bagi setiap individu serta pengalaman dapat diberikan kepada siapa saja agar digunakan dan menjadi acuan serta pembelajaran seseorang. Pengalaman imunisasi merupakan hal yang tidak bisa kita abaikan hanya sesuatu yang bisa kita abaikan.

\section{KESIMPULAN DAN SARAN}

Berdasarkan hasil penelitian yang dilakukan maka dapat ditarik kesimpulan bahwa ada hubungan antara pengetahuan ibu dan sikap dengan imunisasi rubella di Kelurahan Wakangka Kecamatan Kapontori. 
Tidak ada hubungan agama dengan imunisasi rubella di Kelurahan Wakangka Kecamatan Kapontori.

Saran yang dapat diberikan dari hasil penelitian ini yaitu disarankan kepada masyarakat yang ada di Kelurahan Wakangka untuk membawa anaknya mengikuti Imunisasi Rubella agar kedepannya tidak terkena penyakit yang disebabkan karena tidak diimunisasi. Disarankan kepada petugas Imunisasi untuk selalu memantau masyarakat yang memiliki anak usia 1 sampai 15 tahun agar dapat mengikuti kegiatan Imuniasasi MR. Disarankan kepada pihak pemerintah untuk selalu mendukung kegiatan imunisasi yang dilakukan oleh pihak puskesmas.

\section{DAFTAR PUSTAKA}

Dinkes Kabupaten Buton. (2018). Capaian Cakupan Imunisasi Measles Rubella (MR).

Dinkes Kabupaten Buton. (2019). Profil Kesehatan Kabupaten Buton Tahun 2018.

Dinkes Provinsi Sulawesi Tenggara. (2018). Profil Kesehatan Provinsi Sulawesi Tenggara tahun 2017.

Dinkes Provinsi Sulawesi Tenggara. (2019). Capaian Cakupan Imunisasi Measles Rubella (MR).

Gustikawati, D. A. N. (2014). Indikator indonesia sehat 2010 dan pedoman penetapan indikator propinsi sehat dan kabupaten/kota sehat: keputusan menkes nomor 1202/sk/viii/2003. Departemen kesehatan.

Mardijanto, D., \& Hasanbasri, M. (2017). Evaluasi pelaksanaan universal child immunization (UCI) di kabupaten pekalongan. Kesehatan Masyarakat.

Merlinta. (2018). Hubungan Pengetahuan tentang Vaksin MR (Measles Rubella) dan Pendidikan Ibu Terhadap Minat Keikutsertaan Vaksinasi MR Di Puskesmas Kartasura. Naskah Publikasi. http://eprints.ums.ac.id/58354/15/NASK AH PUBLIKASI-3.pdf

Pramitasari, D. A., \& Puteri, I. R. P. (2017). Hubungan Pengetahuan dan Sikap Ibu dengan Kepatuhan dalam Mengikuti Imunisasi Measles-Rubella (MR) Massal Di Posyandu Wilayah Kerja Puskesmas Nganglik II Kabupaten Sleman Yogyakarta. The Shine Cahaya Dunia DIII Keperawatan, 2(2), 54-62. http://ejournal.annurpurwodadi.ac.id/inde x.php/TSCD3Kep/article/view/98

Stefanovic, S., Kavecan, I., Jovanovic, J., \& Kolarski, M. (2016). Rare clinical case of rubela infection diagnosed in neonate period. Journal of Maternal-Fetal and Neonatal Medicine, 29, 111.

Yuliani. (2012). Persepsi Masyarakat Tentang Universal Child Imunization Di puskesmas Bangkinang II dan puskesmas XIII koto Kampar I. Jurnal Kesehatan Masyarakat. 